Int. J. Morphol.,

30(4):1348-1352, 2012

\title{
Commentary: Is the Evidence for Localization of Nephrin on the Slit Diaphragm Rigid?
}

\author{
Comentario: ¿Está la Evidencia para la Localización \\ de Nefrina en el Diafragma de Ranura Rígido?
}

"Wiphawi Hipkaeo; ${ }^{* *}$ Ryoji Suzuki; "**Hiroshi Abe; "Kowit Chaisiwamongkol \& *,"**Hisatake Kondo

HIPKAEO, W.; SUZUKI, R.; ABE, H.; CHAISIWAMONGKOL, K. \& KONDO, H. Commentary: Is the evidence for localization of nephrin on the slit diaphragm rigid?. Int. J. Morphol., 30(4):1348-1352, 2012.

SUMMARY: After careful observation of immuno-electron microscopic findings of the renal glomerular podocyte slit so far published by various authors, it should be noted that no convincing evidence is present for localization of nephrin-immunoreactivity in the slit itself, but that nephrin-immunoreactivity is dominantly localized along the membranes of podocyte pedicles from their tip over a substantial extension. In addition, the notion that the slit diaphragm is composed of strands is compatible with the widely distributed view that the slit strands represent rod-shaped nephrin molecules. However, 3-D findings that the diaphragm is composed of not only strands but also membranous elements have recently demonstrated separately by embedment-free section electron microscopy as well as by frozen/deep-etched replica electron microscopy. It is therefore suggested that the molecular composition of the slit diaphragm remain to be further elucidated, and that it is also necessary to re-consider how nephrin is involved in the renal glomerular filtration based on the exact localization along the podocyte membrane, but not in the slit itself. The present author would welcome any criticism and opinion on his consideration.

KEY WORDS: Glomerulus; Slit; Nephrin; Localization; Immunohistochemistry.

The production of the primary urine from blood plasma in the kidney is accomplished through the renal glomerular filter composed of three structural components: fenestrated endothelia, glomerular basement lamina, and highly specialized epithelia termed podocytes. which elaborate appropriately $40 \mathrm{~nm}$-wide slits by interdigitation of their long foot-processes (Fawcett, 1994). The slits are bridged by a structure termed the slit diaphragm whose cut-view in transmission electron microscopy (TEM) appears as a single line, 3-5 nm wide, with lower electron density than the plasma membrane. Although there have been long debates on which of the three components plays the major contribution to the ultrafiltration, the pendulum has recently been swung from the basement lamina to the slit diaphragm of podocytes with the discovery of a molecule termed nephrin from the renal glomerulus, the demonstration of proteinuria by a mAb against nephrin, and the discovery of mutations in nephrin gene in patients with congenital nephritic syndrome of the Finnish type (CNF) (Kestila et al., 1998; Tryggvason, 1999; Farquhar, 2003; Simons \& Huber, 2008). In further support of the pendulum swing, a molecular domain of nephrin was identified which could undergo homophilic interactions (Barletta et al., 2003; Patrakka \& Tryggvason, 2007). This possible molecular interaction of nephrin, which is assumed to occur in the slit, is well in accord with a dominant ultrastructural view that the slit diaphragm is essentially composed of ladder-strands bridging the slits (Rodewald \& Karnovsky, 1974; Wartiovaara et al., 2004; Simon \& Huber, 2008).

\footnotetext{
* Department of Anatomy, Faculty of Medicine, Khon Kaen University, Khon Kaen 4002, Thailand.

** Department of Anatomy, School of Medicine, Akita University, Akita, Japan.

${ }^{* * *}$ Department of Rhehabilitation, School of Medical Welfare, Tohoku Bunka Gakuen University, Sendai, Japan.
}

This paper is dedicated with heartful mourning to the late Professor Tsuneo Fujita who had served the former editor in chief to the Archivum Histology and Cytology for 40 years, and had proposed the paraneuron concept and retired from his active stage in 1994; and passed away suddenly on Feb 6, 2012. The correspondent author of this article, H.K., used to work as an associate professor under his chairmanship for 6 years in Niigata University School of Medicine Anatomy. The principle in research of the late Prof. Fujita was that accurate and detailed histological findings themselves of given tissues/cells should be a starting point to consider their exact functions, but that the histological study should not be done simply to serve just supports for superficially accepted functional interpretation of the tissues/cells. The present immunohistochemical questionary is compatible with his principle. In addition, without encouragement by the late Prof. Fujita during the associate professorship of H.K., the development of embedment-free section TEM and of subsequent interpretation of findings by the method would not have been completed by H.K. who greatly appreciates the generous chairmanship of the late Prof. Fujita. 
In immunohistochemical studies so far published (Holthofer et al. 1999; Holzman et al., 1999; Barletta et al., 2003; Liu et al., 2003; Done et al., 2008), the intense immunoreaction for nephrin is confined to the glomerulus, and appears in forms of undulating bands, which are approximately $350 \mathrm{~nm}$ wide and delineate the contour of glomerular capillary loops, in immunofluorescence light microscopy. This is easily confirmed in the present article (Fig 1). In immuno-electron microscopy using immunogolds as a marker, it is clear that the immuno-gold particles for nephrin are deposited largely on the plasma membranes of podocyte foot-processes over a substantial extension from their tip. The extension size of the immuno-gold distribution in immune-electron microscopy well corresponds to the thickness of the immunoreactive bands in immuno-light microscopy (Liu et al., 2003; Holthofer et al., 1999; Holtzman et al., 1999). With this correspondence between immuno-light and electron microscopic findings, it is quite reasonable to judge the reliability of the immuno-reaction. However, it should be noted that the immuno-gold particles were rarely found in the slits themselves in most of the studies (for example, please refer to Fig 8 in the article by Holzman et al., 1999). Although some studies clearly showed a few immuno-golds for nephrin in the slits (Tryggvason, 1999; Ruotsalainen et al., 1999; Gerke et al., 2005), it should be noted that the number of the gold particles on the plasma membranes of the podocyte processes was actually null in their studies. This feature is clearly incompatible with the well-correspondence of the immunoreaction size between immuno-light and electron microscopic analyses as described above, suggesting that the reliability of data in the latter studies is questionable.

This correspondence in localization pattern and size between immune-light and electron microscopies, which is crucial to confirm the reliability of immunohistochemical data, is easily duplicated in immunohistochemistry using DAB (diaminobenzidine) as a marker for immunoreaction. It is often debated that sites recognized by immuno-DAB are more expanded than original immunoreactive sites because of enhanced appearance and diffusion of the immunoreaction itself by DAB-reactants. However, this is not the case at least for nephrin because the intense immunoreaction in light microscopy appears as a undulating band which faithfully corresponds to the immuno-fluorescence light microscopic image in terms of the band width and its course (Fig 2). This feature leads to examine the localization of nephrin in immuno-DAB electron microscopy. As a result, the density-increase due to the immunoreaction is never detected at all in the slit itself, in contrast to a marked density-increase of the membranes of podocyte pedicles from their tips over a substantial extension. The extension size of the density-increase corresponds to the width of immuno-reaction for nephrin in immuno-DAB and -fluorescence light microscopy as well as in immune-gold electron microscopy as described above (Figs 3,4). The absence, not presence, of the density increase in the slit is compatible with the rare occurrence of immuno-gold particles in the slit in most previous studies by others as described above, and it further suggests that the enhanced appearance/diffusion of DABimmunoreaction is not necessary to be seriously afraid of as a potential artificial diffusion.

Therefore, the rare occurrence of immuno-golds for nephrin in the slit in most immune-electron microscopic studies so far published is highly problematical in order to conclude that the localization of nephrin is on the slit diaphragm itself. Although some authors may state that the rare occurrence is simply due to the fact that the slit diaphragm is too thin to immunoreact sufficiently, the recent finding on the localization of PV1 (Plasmalemmal Vesicle associate protein 1) in the diaphragm of the endothelial fenestra could antagonizes such a statement (Stan et al., 2004; Stan 2007). In their study, the immuno-gold particles are evidently shown to be deposited on the vesicle diaphragms whose thinness is similar to that of the slit diaphragm in a cut-view in electron microscopy. In short, it is clear from data available at present that any evidence for the localization of nephrin on ladder-strands in the slit diaphragm itself is not concrete. It is thus immature to suppose that the ladder strands represent morphological correlates for the homophilic interaction between the extracellular domains of nephrin molecules on apposed podocyte membranesis. In addition, a recent study in 3D embedment-free section transmission electron microscopy has demonstrated clearly by the present author that the slit diaphragm is composed not only ladderstrands but also membranous elements, the latter of which seems to have been masked by epoxy embedment in conventional TEM (Fig 5) (Kondo 1995; Kondo, 2011). A similar finding was also reported by rapid-frozen and deep-etched replica TEM (Ohno et al., 1996) Repeated to say, the dominant localization of nephrin in the membranes of the podocyte pedicles, not in the diaphragm, is evident, regardless of immuno-gold or immune-DAB immunohistochemical methods. Based on this confirmative histological finding, it seems to be reasonable to re-consider in some other ways through the nephrin-positive portions of podocyte membranes, but not through the slits, the mechanism how nephrin is involved in normal protection of albuminuria. 

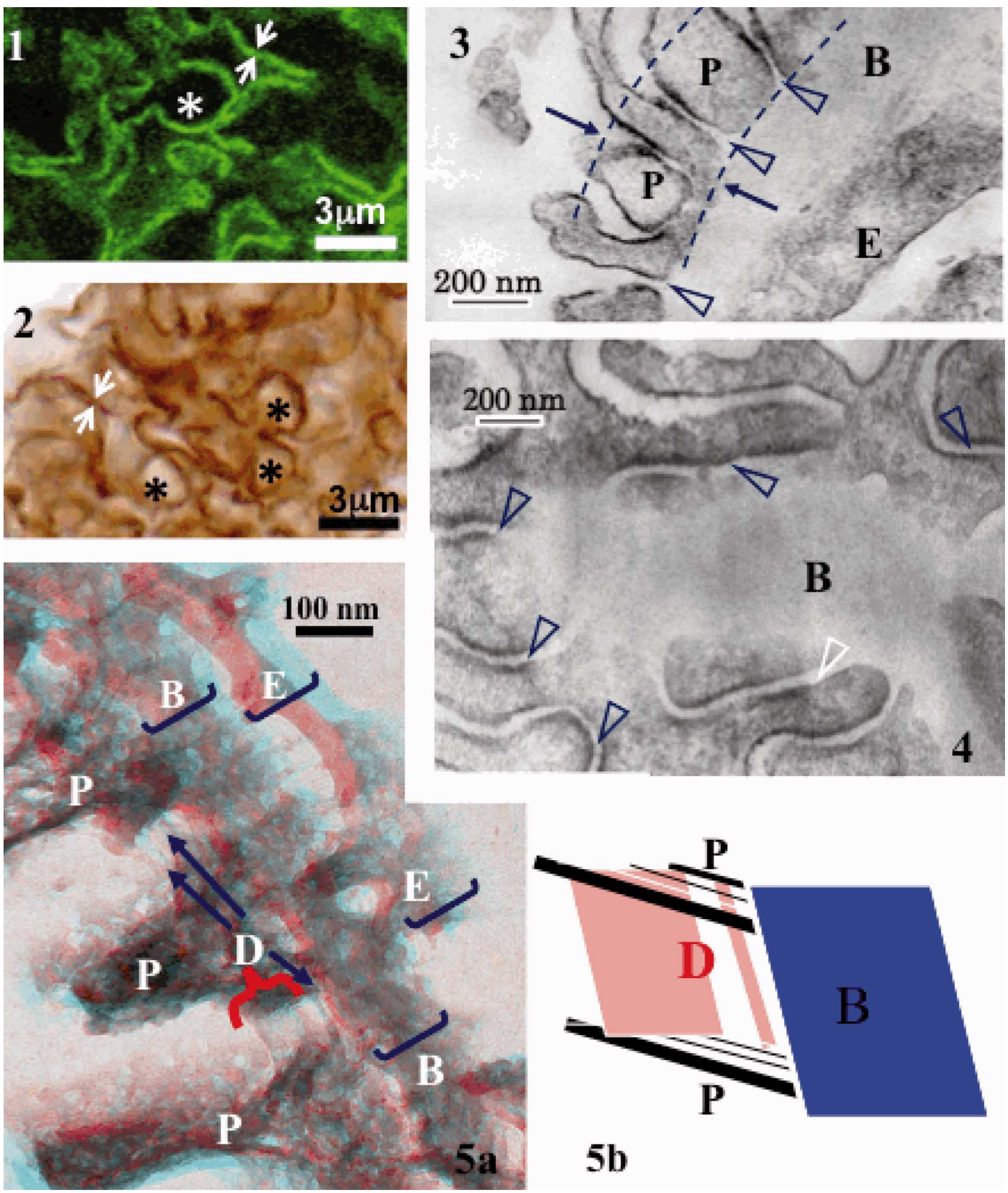

\section{$\mathbf{5 b}$}

Figs 1, 2: Immuno-light micrographs of nephrin (extracellular domain as antigen) localization by immuno-fluorescence (Fig 1) and immunoDAB (Fig 2) in renal glomerulus of adult rats. Note good correspondence in appearance of intensely immunoreactive and undulating bands in terms of their width of about $350 \mathrm{~nm}$ (indicated \& sandwitched by two arrows) as well as their courses between two figures. Asterisks indicate lumens of capillaries delineated by the immunoreactive bands.

Figs 3, 4: Immuno-DAB electron micrographs of a portion of the glomerular filtration site (cut-view in Fig 3 and tangential view in Fig 4) 
HIPKAEO, W.; SUZUKI, R.; ABE, H.; CHAISIWAMONGKOL, K. \& KONDO, H. Comentario: ¿Está la evidencia para la localización de nefrina en el diafragma de ranura rígido?. Int. J. Morphol., 30(4):1343-1347, 2012.

RESUMEN: Después de una cuidadosa observación de los hallazgos inmunoquímicos, vía microscopio electrónico, de la hendidura del podocito glomerular renal ampliamente publicados por varios autores, se debe hacer notar que no existe evidencia convincente de la presencia de inmunorreactividad de nefrina en la hendidura propiamente tal, ya que la inmunorrectividad de nefrina está predominantemente localizada a lo largo de la membrana de los podocitos desde su extremo sobre una sustancial extensión. Agregado a ello, la idea de que el diafragma de la hendidura está compuesto de filamentos es compatible con la visión que los filamentos diafragmáticos representan moléculas de nefrina en forma de varilla. Sin embargo, hallazgos en 3D muestran que el diafragma está compuesto no solamente de filamentos sino que también por elementos membranosos que han sido demostrados recientemente por sección libre de microscopía electrónica (embedmentfree), así como también por microscopía electrónica de réplica por congelación y grabado profundo (frozen/deep-etched). Por lo tanto, se ha sugerido que la composición molecular del diafragma de filtración permanece para ser estudiada en el futuro y que es también necesario reconsiderar como la nefrina está involucrada en la filtración glomerular renal basados en la localización exacta a lo largo de la membrana del podocito pero no en la hendidura misma. A los autores les gustaría recibir alguna crítica u opinión sobre su consideración.

PALABRAS CLAVE: Glomérulo; Slit; Nefrina; Localización; Inmunohistoquímica.

\section{REFERENCES}

Barletta, G. M.; Kovari, I. A.; Verma, R. K.; Kerjaschki, D. \& Holzman, L. B. Neprhin and NEPH1 co-localize at the podocyte foot process intercellular junction and form cis hetero-oligomers. J. Biol. Chem., 278:19266-71, 2003.

Done S.C., M. Takemoto, L. He, Y. Sun, K. Hultenby, C. Betsholtz and K. Tryggvason: Nephrin is involved in podocyte maturation but not survival during glomerular development. Kidney Internatl., 73:697-704, 2008.

Farquhar, M. G. The glomerular basement membrane: not gone, just forgotten. J. Clin. Invest., 116:2090-3, 2006.

Fawcett D.W. A Textbook of Histology. 12th Ed. Chapman \& Hill, New York/London (1994).

Gerke, P. L.; Sellin, O.; Kretz, D.; Petraschka, H.; Zentgraf, T.; Benzing \& Walz, G. NEPH2 is located at the glomerular slit diaphragm, interacts with nephrin and is cleaved from podocytes by metalloproteinases. J. Am. Soc. Nephrol., 16:1639-1702, 2005.
Holthofer, H.; Ahola, H.; Solin, M. L.; Wang, S.; Palmen, T.; Luimula, P.; Miettinen, A. \& Kerjaschki, D. Nephrin localizes at the podocyte filtration slit area and is characteristically spliced in the human kidney. Am. $J$. Pathol., 155:1681-7, 1999.

Holzman, L. B.; John, P. L. St.; Kovari, I. A.; Verma, R.; Holthofer, H. \& Abrahamson, D. R. Neprhin localizes to the slit pore of the glomerular epithelial cell. Rapid Communication. Kidney Internatl., 56:1481-491, 1999.

Kestila, M.; Lenkkeri, U.; Mannikko, M.; Lamerdin, J.; McCready, P.; Putaala, H.; Ruotsalainen, V.; Morita, T.; Nissinen, M.; Herva, R.; Kashtan, C. E.; Peltonen, L.; Holmberg, C.; Olsen, A. \& Tryggvason, K. Positionally cloned gene fro a novel glomerular protein - nephrin - is mutated in congenital nephritic syndrome. Mol. Cell. 1:575-582, 1998.

Kondo, H. On the real structure of the cytoplasmic matrix: learning from the embedment-free electron microscopy. Arch. Histol. Cytol., 58:397-415, 1995.

corresponding to that as shown in Fig 2. The $350 \mathrm{~nm}$-width of intensely immunoreaction bands shown by arrows in immuno-light microscopy in Fig 2 corresponds to a zone delineated \& sandwithed by two broken lines and thin arrows which are superimposed on the podocyte pedicles $(\mathrm{P})$ in Fig 3. Note the immuno-reaction represented by thickened electron density along the membrane of podocyte pedicles within the broken line-enclosed zone, but no increase in the electron density in spaces (slits) between two adjacent podocyte pedicles (open arrowheads). Also note the same feature in tangential section of the filtration site in which no increase in electron density is seen in the slit (open arrowheads) in contrast to the density increase of adjacent podocyte membranes (Fig 4). B: basement lamina, E: endothelium.

Fig 5a, 5b: three-dimensional views of glomerular filtration site in embedment-free section TEM. Please observe Fig 5a with red/blue glasses for stereo-viewing. Note in slit diaphragm a membranous component indicated by red parenthesis and strand-components are indicated by $\mathrm{D}$ and thin arrows. Fig $5 \mathrm{~b}$ represents schematic drawing of the slit in Fig $5 \mathrm{a}$ as viewed in stereo in a direction from endothelium to epithelium. Podocyte pedicles (P) are colored with black, membranous component and strand- component of slit diaphragm (D) are colored with pink, while basement lamina (B) is colored with blue. 
HIPKAEO, W.; SUZUKI, R.; ABE, H.; CHAISIWAMONGKOL, K. \& KONDO, H. Commentary: Is the evidence for localization of nephrin on the slit diaphragm rigid? Int. J. Morphol., 30(4):1348-1352, 2012.

Kondo, H. Disclosure in 3D of slit-membrane as well as strands, and en-face basal lamina in situ of renal glomerulus of normal rats in embedment-free section transmission electron microscopy. Microsc. Res. Tech., 74:142-7, 2011.

Liu, G., B. Kaw, J. Kurfis, S. Rahmanuddin, Y.S. Kanvar and S.S. CHugh: Neph1 and nephrin interaction in the slit diaphragm is an important determinant of glomerular permeability. J. Clin. Invest., 112:209-14, 2003.

Ohno, S.; Baba, T.; Terada, N.; Fujii, Y. \& Ueda, H. Cell biology of kidney glomerulus. Int. Rev. Cytol., 166:181230, 1996.

Patrakka, J.; \& Tryggvason, K. Nephrin- a unique structural and signaling protein of the kidney filter. Trends Mol. Med., 13:396-403, 2007.

Rodewald, R. \& Karnovsky, M. J. Porous substructure of the glomerular slit diaphragm in the rat and mouse. $J$. Cell Biol., 60:423-33, 1974.

Ruotsalainen, V.; Ljungberg, P.; Wartiovaara, J.; Lenkkeri, U.; Kestila, H.; Jalanko, C.; Holmberg, K. Tryggvason, H. Nephrin is specifically located at the slit diaphragm of glomerular podocytes. Proc. Natl. Acad. Sc.i USA., 96:7962-7, 1999.

Simons, M. \& Huber, T. B. It's not all about nephrin. Kidney, Internatl., 73:671-3, 2008.

Stan, R.V.; Tkachenko, E. \& Niesman. IR. PV1 is a key structural component for the formation of the stomatal and fenestral diaphragms. Mol. Biol. Cell., 15:3615-30, 2004.

Stan, R.V. Endothelial stomatal and fenestral diaphragms in normal vessels and angiogenesis. J. Cell. Mol. Med., 11:621-43, 2007.

Tryggvason, K. Unraveling the mechanisms of glomerular ultrafiltration: nephrin, a key component of the slit diaphragm. J. Am. Soc. Nephrol., 10:2440-5, 1999.

Wartiovaara, J, L.G.; Ofverstedt, J.; Khoshnoodi, J.; Zhang, E.; Makela, S.; Sandin, V.; Ruotsalainen, R.H.; Cheng, H.; Jalanko, U.; Skoglund \& K. Tryggvason: Nephrin strands contribute to a porous slit diaphragm scaffold as reveald by electron tomography. J. Clin. Invest., 114:1475-83, 2004.
Correspondence to:

H. Kondo

Department of Rehabilitation

School of Medical Welfare

Tohoku Bunka Gakuen University

Sendai

JAPAN

Email: hisatakekondo@hotmail.com hkondo@rehab.tbgu.ac.jp

Received: 01-09-2012

Accepted: 12-10-2012 